\title{
Poesía arcaica griega (Siglos VII-V a. C.) Tomo I: Poesía Parenética. Calino, Tirteo, Arquíloco, Mimnermo, Alceo, Solón, Simónides. Estudio preliminar, versión, notas, comentarios e índices de Bernardo Berruecos Frank. México: UNAM (BSGRM), 2018, p. DXL+21. ISBN: 978-607-30-0203-5
}

Leonor Hernández Oñate*

Recebido em: 11/12/2019

Aprovado em: 04/03/2020
B ernardo Berruecos Frank's Poesía arcaica griega (Siglos VII-V a.C.) contributes grandly to the scholarly work written in Spanish dealing with archaic poetry and inserts itself among the thriving trend of lyric studies worldwide. This anthology with an introduction, Spanish translation and commentary of Greek poetic fragments from the archaic period is the first volume of a larger, currently in progress, project that intends to collect and study a wide range of forms of discourse. This initial delivery includes the work of seven poets: Callinus, Tyrtaeus, Archilochus, Mimnermus, Alcaeus, Solon, and Simonides. The fact that most of these authors are mainly known as elegiac and iambic poets conveys, thus, one of the most interesting features of Berruecos Frank's work: the concept of parainesis, which guides the criterion for the selection of the poems. Parainesis, as the author tells us, is a narrative exhortation to the audience, a guide for communal behavior, and is lexically composed by the noun aivos (story, proverb, counsel), and the preposition $\pi \alpha \rho \alpha$ (Cf. p. X, LV). Hence, parainetic poetry, term with which the texts in this anthology are labeled, has an exhortative nature and intends for a delivered discourse to have a pragmatic effect on the audience (Cf. p. LIX-LXXXIV).

The fragments of parainetic nature collected within this anthology are classified into three distinct categories: war parainesis (parénesis guerrera), heroic remembrance and sepulchral epigram (rememebranza heroica y epigrama sepulcral), and political parainesis (parénesis politica), according to three different contexts of
*Doctoranda en Humanidades, Universidad Autónoma MetropolitanaIztapalapa. Docente de literatura griega y de cultura clásica en los Colegios de Letras Clásicas y Letras Modernas, Facultad de Filosofía y Letras, Universidad Nacional Autónoma de México.

leoint88@hotmail.com 
exhortation and their pragmatic function: war, death and politics. The second category also constitutes a novel feature of Berruecos Frank's book, which is the inclusion of epigrams, in this case all by Simonides (fr. 86 W?, IX P,VI P, XXII a-b P, VIII P). This genre is normally studied and read on its own, and it is certainly interesting to read Simonides's funerary couplets celebrating the soothsayer Megistias, who died with Leonidas in the Thermopylae (VI P), next to Alcaeus's well-known armory poem (357 LP). This unique arrangement based on narrative and functional principles allows for a different and very revealing reading of the social role and nature of Greek archaic discourse.

As I stated previously, Berruecos Frank's Spanish translation is preceded by an ample preliminary study, which acts as an introduction and establishes important methodological aspects of the oeuvre. The initial section would be especially useful for students, as it includes a discussion of basic concepts, such as memory, orality (p. XXV-XXVIII) and genre (p. XXIX-LIX), as well as the definition and history of parainesis (p. LV-LXXXIV). Later on the author offers biographical and updated bibliographical data of each poet, and finishes this first chapter with a large discussion of each of the fragments collected in the anthology, including a very useful status quaestionis of their analysis and interpretation.

The text and translations are followed by a literary and linguistic commentary, although Berruecos Frank focuses more poignantly on the latter, explaining with detail the syntactical, lexical and grammatical characteristics of relevant verses. The length of the first and third sections is in contrast with the considerably shorter chapter of text and translation, both of which are actually a rather small part of the book as a whole. An Index locorum, Index nominum and Bibliography are also included.

Although the translation is minimal, it is also quite successful. The editorial collection to which it belongs, the Bibliotheca Scriptorum Graecorum et Romanorum Mexicana (hereinafter referred to as BSGRM) ${ }^{1}$ has been traditionally known for practicing a literal translation style that non-classicist Spanish speakers find extremely complicated to understand, which caused this collection to be limited to the knowledge and use of an only-specialist audience, mainly Classics students and teachers. On the contrary, Berruecos Franks attempts at creating versions that are understandable and also pay close attention to the Greek text, so that a more ample audience can approach it: the transparence of the translations is appealing to non-specialist, everyday readers, but the complexity of the commentaries are useful to scholars and students. Perhaps an example may suffice, Tyrtaeus' well-known fr. 10.1-4 West (Cf. p. 3):

\footnotetext{
${ }^{1}$ Edited by de Universidad Nacional Autónoma de México (UNAM), it has been the leading collection for the translation of Greek and Roman literature in Mexico. Berruecos Frank's book aims at marking a new beginning, the first volume that emerges from an approach that focuses both in technical and literary issues to spread the Classics, in which translation and commentary are more balanced, providing thus an integral tool for understanding the texts.
} 


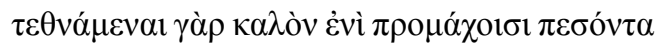

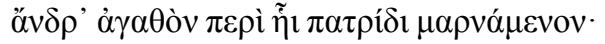

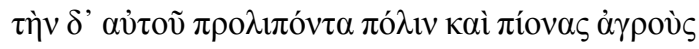

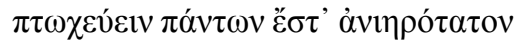

Pues es bello que muera caído en el frente de la batalla

Un hombre valiente luchando por su patria.

Pero, dejar la ciudad y los fértiles campos

Y mendigar es lo más lamentable de todo...

Attention to the basic syntactic structure of Spanish is shown. The Greek sentence has a complex syntax, since $\kappa \alpha \lambda$ óv, in the middle of the first verse, is the main verb that calls for the infinitive $\tau \varepsilon \theta v \alpha \dot{\mu} \mu \varepsilon v \alpha$, which opens the poem; the subject, $\alpha v \delta \rho$ ' $\alpha \gamma \alpha \theta$ óv, is beneath the infinitive in verse 2 , and has two participles, $\pi \varepsilon \sigma o ́ v \tau \alpha$ and $\mu \alpha \rho v \alpha ́ \mu \varepsilon v o v$, respectively in verses 1 and 2. Nevertheless, Berruecos Frank manages to create a translation that sounds natural and yet poetically crafted in Spanish. Furthermore, he begins his translation with pues, interpreting this way $\gamma$ ó $\rho$ and thus preserving this peculiarity of the fragment that has even made some scholars suspicious of the existence of a previous part of the poem which would be now lost, as the author informs in the Commentary section (p. CCLXXV-CCLXXVI).

Despite the fact that I particularly applaud the depth of the commentary and the preliminary study, and that I have mentioned that the Spanish versions are accessible to an ample audience, the narrowness of the section containing the Greek text and its translations can make it difficult to access. The reader can easily get lost among its many pages, 584, out of which only 42 (21 pairs) contain the fragments and its Spanish versions.

I believe that the BSGRM starts an exciting new path with the publication of this anthology. Hopefully, future volumes will keep including essential authors, as Alcaeus or Archilochus, who are nevertheless very much in need of study in Mexican scholarship. However, in order to be current and useful, they should take into consideration new findings and poets that are not traditionally read along with other lyric poets, like Timotheus of Miletus or the carmina convivalia and popularia. The novelty of the emphasis, which in this case was the parainesis, is also to be kept in mind for further selections. 